\title{
DESAIN BAHAN AJAR MATERI GELOMBANG DAN BUNYI MODEL INKUIRI TERBIMBING UNTUK MELATIHKAN KETERAMPILAN PROSES SAINS SISWA SMP
}

\author{
Latifatul Jannah"), Mohamad Nur'), Suyono ${ }^{3)}$ \\ ${ }^{1)}$ Mahasiswa Program Studi Pendidikan Sains, Program Pascasarjana Universitas Negeri Surabaya \\ ${ }^{2), 3)}$ Dosen Pascasarjana Prodi Pendidikan Sains Universitas Negeri Surabaya \\ E-mail: jannatifaa@gmail.com
}

\begin{abstract}
Abstrak: Penelitian ini bertujuan untuk menghasilkan bahan ajar yang valid, praktis, dan efektif. Penelitian desain bahan ajar ini menggunakan model 4-D (Four-D Model) yang dibatasi pada tiga tahapan, yaitu pendefinisian (define), perancangan (design), dan pengembangan (develop). Hasil desain bahan ajar diujicobakan pada siswa kelas VIII SMPN 30 Surabaya semester genap tahun ajaran 2014/2015 dengan One-Group Pretest-Posttest Design. Pengumpulan data menggunakan observasi, tes, dan angket. Teknik analisis data menggunakan analisis deskriptif kuantitatif dan kualitatif. Hasil penelitian ini menunjukkan: 1) bahan ajar yang dikembangkan valid untuk melatih keterampilan proses sains siswa SMP; 2) Keterlaksanaan RPP yang mencapai 99\% dan aktivitas belajar siswa menunjukkan behan ajar yang didesain terkategori praktis dalam melatih keterampilan proses sains siswa SMP; dan 3) Respon positif siswa terhadap bahan ajar, dan peningkatan keterampilan proses sains menunjukkan bahan ajar yang didesain efektif untuk melatihkan keterampilan proses sains. Disimpulkan bahwa bahan ajar yang didesain valid, praktis, dan efektif untuk melatihkan keterampilan proses sains siswa SMP kelas VIII.
\end{abstract}

Kata kunci: Model pembelajaran kooperatif, think-pair-share (TPS), Mind Map, Hasil Belajar

Abstract: The objective of this research is to produce an intervention which is valid, practical, and effective. This intervention design research is conducted through model 4-D that limited to three phases, that is define, design, and develop. Those intervention is tried out at eight class on SMPN 30 Surabaya in academic year 2014/2015 with one-group pretest-posttest design. Data were collected using observation method, tests, and questionnaires. Data are analyzed using descriptive analysis quantitatively and qualitatively. The results show that 1) the intervention are valid categorized; 2) the implementation result of lesson plan until $99 \%$, and the student activity show that the intervention is practice categorized to train scientific process skills, 3) students positively respond toward intervention, and the increasing of scientific process skills show that the intervention is effective to train scientific process skills. It can be concluded that the intervention design is valid, practice and effective to train students scientific process skills.

Keywords: Intervention, Guided Inquiry, and Science Process Skills.

\section{PENDAHULUAN}

Implementasi Kurikulum 2013 menjadikan Buku Siswa dan Buku Guru sebagai salah satu sarana yang sudah disiapkan Kemendikbud sesuai dengan Permendikbud No. 71 Tahun 2013 tentang buku teks. Permendikbud menjelaskan Buku Guru merupakan pedoman bagi guru dalam pengajaran dan pembelajaran. Sedangkan Buku Siswa adalah sumber belajar siswa yang memuat materi pembelajaran, kegiatan siswa, latihan soal, rangkuman, peta konsep, serta evaluasi. Penjelasan tersebut sejalan dengan yang dikemukakan Prastowo (2013) yang menyatakan bahwa Buku Siswa merupakan sumber belajar siswa yang memuat judul, kegiatan siswa, rangkuman materi, evaluasi, dan tugas. Buku Siswa ideal hendaknya mengacu pada Buku Siswa berstandar internasional.
Peneliti mengacu pada Buku Siswa Glencoe yang diterbitkan McGraw-Hill. Buku tersebut memiliki karakteristik sebagai berikut: 1) desain buku memiliki nilai estetika yang baik, 2) konten materi yang kontekstual dan penyajian materi yang komunikatif, 3) melatihkan keterampilan proses sains, 4) dan melatihkan High Order Thinking Skills (HOTS). Empat poin tersebut menjadi pedoman penulis dalam pengembangan Buku Siswa.

Buku Siswa merupakan salah satu media pembelajaran yang mempunyai peran penting dalam keberhasilan kegiatan pembelajaran. Buku Siswa dapat dirancang dan digunakan dengan baik jika memperhatikan sejumlah prinsip dalam pembelajaran. Pemilihan dan penyajian materi serta penggunaan bahasa dan keterbacaan juga menjadi pertimbangan 
penting. Semua komponen tersebut harus berlandaskan kebutuhan di mana buku tersebut dikembangkan. Umumnya semua sekolah menggunakan Buku Siswa sebagai buku ajar utama. Hal ini mengindikasikan bahwa Buku Siswa merupakan bagian penting dalam proses pembelajaran (Prastowo, 2013).

Buku Guru berfungsi menuntun guru dalam melaksanakan pembelajaran. Buku Guru ideal adalah Buku Guru yang memiliki keselarasan/kegayutan dengan Buku Siswa, Buku Guru mampu mengejawantahkan setiap bagian yang terdapat pada Buku Siswa. Buku Guru IPA Glencoe merupakan salah satu contoh Buku Guru ideal yang memiliki karakteristik: 1) memiliki halaman yang sama dengan halaman Buku Siswa, letak Buku Siswa di bagian tengah dan Buku Guru di sisi samping dan bawah, 2) terdapat langkah-langkah pembelajaran dan pengajaran yang memandu guru, 3) mencantumkan kunci jawaban pada setiap soal yang terdapat pada Buku Siswa, 4) mencantumkan identifikasi miskonsepsi pada bagian yang diperlukan, 5) memberikan alternatif kegiatan jika kegiatan utama tidak dapat terlaksana, dan 6) menjelaskan indikator-indikator KPS secara khusus di bagian awal buku.

Buku Siswa dan Buku Guru IPA SMP Kurikulum 2013 saat ini masih dalam tahap revisi dan penyempurnaan. Oleh karena itu peneliti dengan tim telah melakukan telaah terhadap Buku IPA Guru Kurikulum 2013 kelas VII dan VIII SMP Kurikulum 2013. Telaah yang dilakukan peneliti terhadap Buku Guru dan Buku Siswa SMP Kurikulum 2013 yang diterbitkan Kemendikbud dibatasi pada kelas VIII bab Indera Pendengaran dan Sistem Sonar pada Makhluk Hidup dan menghasilkan beberapa temuan terkait kelebihan dan kekurangannya.

Menanggapi permasalahan tersebut, peneliti berupaya mencari solusi perbaikan dengan mengacu pada tuntutan pengembangan Kurikulum 2013. Solusi yang akan ditawarkan berupa pengembangan bahan ajar yang mengacu pada bahan ajar standar internasional serta referensi standar dalam pengembangan intervensi. Mengacu pada buku teks berstandar internasional, Buku Siswa dan Buku Guru yang ideal memiliki ciri-ciri sebagai berikut:

1. Desain Buku Siswa dan Buku Guru diatur sehingga memiliki halaman yang sama, kesamaan halaman ini banyak memberi kemudahan dan kepraktisan pada guru saat proses pembelajaran. Pengaturan halaman yang sama juga mempermudah dalam mengecek dan memastikan kesinkronan isi kedua buku tersebut. Semua yang disajikan pada Buku Siswa dibahas pada Buku Guru, setiap materi dan kegiatan yang ada pada Buku Siswa diberikan langkah pembelajaran pada Buku Guru, setiap soal dan lembar kerja siswa pada Buku Siswa diberikan kunci jawaban pada Buku Guru tanpa harus membuka dua buku dengan halaman yang berbeda, guru hanya memegang satu buku, yaitu Buku Guru, sedangkan siswa memegang Buku Siswa saja.

2. Ranah pembelajaran yang digunakan mengacu pada ranah yang telah disepakati secara internasional, yaitu afektif, kognitif, dan psikomotor.

3. Jenis pengetahuan terdiri dari faktual, konseptual, prosedural, dan metakognisi.

4. Kegiatan pembelajaran berpusat pada siswa dan berpusat pada guru secara proporsional, disesuaikan dengan materi dan tujuan pembelajaran.

5. Kegiatan pembelajaran dipenuhi dengan kegiatan seperti minilab, diskusi, pengamatan, dan eksperimen yang terintegrasi dengan keterampilan proses sains dasar dan terpadu.

6. Diberikan alternatif kegiatan jika kegiatan utama tidak memungkinkan untuk dilakukan.

7. Identifikasi miskonsepsi untuk meminimalisir adanya kesalahan konsep dan pemahaman siswa.

8. Penjabaran fase-fase pembelajaran yang jelas dan terarah.

9. Memenuhi validitas isi dan validitas konstruk. Nieveen (2007) menyatakan bahwa untuk membuat intervensi yang baik maka intervensi harus divalidasi secara konstruk dan konten.

Beberapa ciri buku ideal yang disebut di atas, menjelaskan pentingnya mengintegrasikan keterampilan proses sains dasar dan terpadu ke dalam proses pembelajaran. Hal ini perlu diperhatikan mengingat pendekatan saintifik dan keterampilan proses sains telah dijabarkan di bagian awal Buku Guru Kurikulum 2013. Namun pada implementasinya tidak dilatihkan secara menyeluruh.

Salah satu yang memfasilitasi siswa untuk mencapai indikator keterampilan proses sains menurut pandangan konstruktivis adalah model inkuiri terbimbing. Inkuiri terbimbing melibatkan siswa secara aktif dalam proses pembelajaran (Sanjaya, 2009). Oleh karena itu penelitian yang ingin diangkat peneliti adalah desain bahan ajar dengan model inkuiri terbimbing untuk melatihkan keterampilan proses sains siswa.

Peneliti ingin mendesain bahan ajar khususnya Buku Siswa dan Buku Guru IPA dengan fitur-fitur: 1) Domain pembelajaran mengacu pada standar internasional. 2) Jenis pengetahuan faktual, konseptual, prosedural, dan metakognisi. 3) Menerapkan model pembelajaran yang berpusat pada siswa dan berpusat pada guru. 4) indikator keterampilan proses sains yang lengkap. 5) Menerapkan HOTS. 6) Desain Buku Guru menjadi satu dengan Buku Siswa, Silabus, RPP, dan lembar penilaian. 7) Menggunakan referensi standar mutakhir sebagai referensi utama dalam pengembangan buku. 


\section{METODE PENELITIAN}

Jenis penelitian ini adalah penelitan desain karena mendesain bahan ajar. Penelitian desain merupakan kajian sistematik atas perancangan, pengembangan dan pengevaluasian intervensi kependidikan (seperti program, strategi-strategi dan bahan-bahan pengajaranpembelajaran, produk dan sistem) sebagai solusi untuk masalah-masalah kompleks dalam praktik kependidikan. Penelitian desain ditujukan pada pendalaman pengetahuan tentang karakteristikkarakteristik intervensi serta proses pendesainan dan pengembangan (Nieveen, 2007). Subjek penelitian adalah bahan ajar IPA model inkuiri terbimbing untuk melatihkan keterampilan proses sains dan subjek uji coba II pada penelitian ini adalah siswa kelas VII SMP sebanyak 27 siswa.

Model pengembangan yang digunakan di samping merujuk Nieveen (2007) juga mengadaptasi model 4D yang dikemukakan oleh Thiagarajan, et al. (1974). Proses pengembangan terdiri dari empat tahap, yaitu define, design, develop, dan disseminate. Pengembangan perangkat yang dilakukan hanya sampai pada tahap ketiga karena diterapkan terbatas.

Rancangan penelitian menggunakan rancangan onegroup pretest-posttest design. Rancangan penelitian ini melibatkan satu kelompok yang diobservasi pada tahap pretest $\left(O_{I}\right)$ yang kemudian dilanjutkan dengan perlakuan tertentu $(X)$ dan posttest $\left(O_{2}\right)$ (Sugiyono, 2014). Teknik pengumpulan data yang digunakan dalam penelitian ini adalah: dokumentasi, pengamatan, tes dan angket. Analisis datanya peneliti menggunakan teknik analisis data kuantitatif dan kualitatif. Analisis data dalam penelitian ini mendeskripsikan validitas, efektivitas, dan kepraktisan Prototipe Buku Guru dan Buku Siswa. Analisa data yang dilakukan bersifat induktif berdasarkan fakta-fakta yang digunakan untuk menjawab rumusan masalah yang telah dirumuskan dalam penelitian lebih menekankan makna dari pada generalisasi (Sugiyono, 2014). Perangkat pembelajaran dinyatakan layak digunakan jika minimal tingkat validitas mencapai kategori valid dengan skor minimal 2.60 (Ratumanan \& Laurens, 2006).

\section{HASIL PENELITIAN DAN DISKUSI}

\section{A. Validitas Bahan Ajar}

Uji coba bahan ajar yang didesain menggunakan model pembelajaran inkuiri terbimbing. Model inkuiri dipilih karena sangat tepat untuk melatihkan keterampilan proses sains. Agar tidak terjadi kesalahan konsep dalam mendesain bahan ajar, maka peneliti sebagai perlu ditera pemahamannya oleh validator (expert judgement). Penilaian pemahaman peneliti dilakukan dengan melihat/menilai dari dua aspek, yaitu pemahaman validitas konstruk (kesesuaian antara setiap fase dalam model inkuiri terbimbing dengan teori belajar pendukung yang diacu oleh peneliti) dan pemahaman validitas konten (model inkuiri terbimbing memenuhi aspek kebutuhan (need) dan kemutakhiran (state of the art) (Nieveen, 2007). Keenam expert sepakat (dengan percentage of agreement yang tinggi) memberikan penilaian sebagai berikut: (1) peneliti telah memahami konstruk teori dari fase-fase model inkuiri terbimbing yang akan digunakan dan (2) peneliti telah memahami aspek-aspek kebutuhan siswa dan kemutakhiran dalam implementasi model inkuiri terbimbing. Artinya, peneliti/pengembanng telah memahami konstruk teori yang mendasari digunakannya model inkuiri terbimbing dalam uji coba bahan ajar yang dikembangkan. Dengan demikian, kekhawatiran terjadinya kesalahan konsep dalam pengembangan bahan ajar tidak terbukti. Artinya, apa yang dipersyaratkan oleh Nieveen (2007) telah dipenuhi.

Validitas Buku Guru dinilai dari delapan aspek yang merepresentasikan ciri buku guru yang baik dan fiturfitur yang seharusnya dipenuhi. Keenam validator (expert) sepakat atau memiliki kesepahaman yang tinggi (percentage of agreement 97\%) untuk menyatakan bahwa: (1) bagian awal dari Buku Guru telah menjelaskan segala aspek yang dibutuhkan di dalamnya (yaitu terdiri atas: Kata Pengantar, Pembelajaran IPA Kurikulum 2013, Pendekatan Saintifik dan Keterampilan Proses Sains dalam Kurikulum 2013, Model Pembelajaran, Penilaian, Teori Belajar, RPP, dan Pengorganisasian Bab), (2) Silabus dan RPP yang merupakan bagian integral dari Buku Guru dengan fungsi sebagai pedoman dalam kegiatan pembelajaran telah dikembangkan sangat baik (sangat valid), (3) Rumusan indikator pembelajaran yang terjabarkan dalam setiap pembelajaran pada Buku Guru sangat valid, menunjukkan bahwa rumusan indikator telah sesuai dengan KI dan KD yang akan dibelajarkan, (4) Indikator KPS yang dilatihkan kepada siswa (merumuskan hipotesis, identifikasi variabel, definisi operasional variabel, mengumpulkan dan menyajikan data pada tabel, menganalisis data, dan menyimpulkan data) adalah sangat valid, (5) muatan HOTS di dalam Buku Guru seperti berpikir kritis (cek bagian), berpikir kreatif (percobaan lanjutan), dan metakognisi (cek keterbacaan, peta konsep) adalah sangat valid, (6) Domain pembelajaran yang digunakan pada Buku Guru (afektif, kognitif, dan psikomotor) sudah sesuai dengan domain yang digunakan pada komponen bahan ajar lainnya (Silabus, RPP, Buku Siswa, dan LP), (7) Kegayutan Buku Guru dan Buku Siswa, yaitu desain (kesamaan halaman buku) dan isi (petunjuk guru) berkategori sangat valid. Dengan demikian, Buku Guru yang dikembangkan layak untuk diujicobakan.

Seperti telah dijelaskan sebelumnya bahwa Buku Siswa yang dikembangkan dalam penelitian ini 
merupakan bagian yang tidak terpisahkan dari Buku Guru. Keenam expert telah memberikan penilaian yang sangat valid atas Buku Siswa yang dikembangkan (percentage of agreement 97\%), bahwa: (1) bagian awal dari buku sangat valid, artinya telah memberikan penjelasan atas segala aspek yang dibutuhkan atau harus dipenuhi di dalam sebuah buku dan (2) komponen-komponen lain yang merupakan bagian yang tidak terpisahkan dari Buku Guru berlaku sebagaimana yang berlaku pada Buku Guru. Buku Siswa ini selanjutnya diujicobakan untuk pengujian kepraktisan dan keefektifan bersama-sama dengan Buku Guru, dengan harapan terbukti praktis dan efektif.

Kesepuluh aspek yang dinilai dari LKS mendapat penilaian expert dengan kriteria sangat valid (skor 4,0). Keenam expert memiliki kesepahaman yang tinggi dalam memberikan penilaian terhadap LKS yang dikembangkan (percentage of agreement 100\%).

Lembar Penilaian Kognitif Produk yang terdiri dari 27 butir soal pilihan ganda yang mewakili 12 indikator soal dan mencakup tingkatan kognitif mulai dari mengingat, memahami, menerapkan, menganalisis, dan mengevaluasi semuanya mendapat penilaian dari expert dengan kategori sangat valid kecuali pada soal 6, 11, 16 berkategori valid. Keenam expert memiliki kesepahaman yang tinggi dalam memberikan penilaian terhadap LP yang dikembangkan (percentage of agreement $97 \%$ ).

Lembar Penilaian Kognitif Proses Kinerja sebenarnya adalah format LKS yang diperuntukkan mengukur kemampuan kognitif proses kinerja yang terdiri atas 6 (enam) indikator soal dan masing-masing terjabarkan dalam satu atau beberapa butir soal berbentuk esai. Masing-masing butir itu untuk mengukur berturut-turut merumuskan hipotesis, mengidentfikasi variabel, merumuskan definisi operasional variabel, mengumpulkan data, menganalisis data, dan merumuskan simpulan. Lima butir soal dari enam soal yang bersesuaian dengan indikator keterampilan proses sains itu mendapatkan penilaian dari expert dengan kategori sangat valid, kecuali butir soal untuk indikator merumuskan definisi operasional variabel mendapat penilaian berkategori valid. Keenam expert memiliki kesepahaman yang tinggi dalam memberikan penilaian (percentage of agreement $93 \%$ ).

\section{B. Kepraktisan Prototipe Bahan Ajar}

Kepraktisan Bahan Ajar yang dikembangkan diukur dari: (1) keterbacaan Bahan Ajar, (2) dukungannya terhadap keterlaksanaan pembelajaran, (3) penciptaan terhadap aktivitas siswa, dan (4) kendala.

Keterbacaan Bahan Ajar meliputi keterbacaan atas Buku Siswa dan LKS. Untuk Buku Siswa, sebagian besar siswa $(83,33-100 \%)$ menyatakan bahwa bahasa yang digunakan pada Buku Siswa mudah dibaca dan dipahami. Sebagian besar siswa itu juga memberikan penilaian yang baik dan positif terhadap aspek penampilan, konten/isi, dan gambar/ilustrasi. Hal yang sama juga terjadi atas LKS. Setelah mengikuti pembelajaran dengan menggunakan LKS yang dikembangkan peneliti, sebagian besar siswa $(83,33-$ $100 \%)$ memberikan penilaian yang positif terhadap penampilan, kejelasan konten/isi, huruf dan bahasa, serta kejelasan gambar ilustrasi pada LKS.

Hasil pengamatan keterlaksanaan RPP menunjukkan bahwa persentase tingkat keterlaksanaan RPP sangat baik. Hasil ini menunjukkan bahwa perangkat pembelajaran yang dikembangkan memenuhi aspek kepraktisan, yaitu bahan ajar dapat diterapkan dengan mudah (Nieveen, 2007).

Hasil pengamatan aktivitas siswa pada uji coba I menunjukkan bahwa terjadi peningkatan persentase aktivitas siswa. Hal ini berarti bahwa seiring siswa mulai terbiasa dan terlatih dengan model pembelajaran yang diberikan guru di kelas maka guru mulai mengurangi bentuk bimbingan sedikit demi sedikit hingga siswa dapat melakukan pembelajaran dengan lebih mandiri. Hal positif lain juga ditemukan saat uji coba II, bahwa aktivitas siswa selama pembelajaran mengalami peningkatan frekuensi pada beberapa aktivitas, seperti mendiskusikan tugas dan melakukan pengamatan, merencanakan eksperimen, melakukan eksperimen atau bekerja.

Sebagaimana pada uji coba I, pada uji coba II juga ditemukan hambatan dalam pembelajaran. Peneliti berusaha untuk meminimalisir efek dari hambatan tersebut dengan mencari solusi alternatif yang dapat dilakukan. Dengan demikian, hambatan yang terjadi telah dapat diatasi tanpa kesulitan berarti. Adanya kendala yang demikian itu, semakin memotivasi peneliti untuk senantiasa memanfaatkan model pembelajaran inkuiri terbimbing meskipun membutuhkan waktu yang cukup untuk perencanaan, pengawasan dan kontinyuitas karena secara berangsurangsur memudahkan para siswa ke arah pembelajaran mandiri (Kuhlthau et al., 2007). Di samping itu, dukungan empiris juga diberikan oleh Amalia dkk (tt) yang menyimpulkan bahwa pembelajaran inkuiri menuntun siswa memperbaiki proses belajar untuk hasil belajar maksimal.

\section{Keefektivan Prototipe Buku Guru dan Buku Siswa}

Keefektifan Bahan Ajar yang dikembangkan diukur dari: (1) dampaknya terhadap hasil belajar dan (2) respon siswa. Hasil belajar yang dijadikan ukuran meliputi: (a) hasil belajar kognitif produk, (b) hasil belajar kognitif proses, (c) hasil belajar afektif, dan (d) hasil belajar psikomotor.

Baik pada uji coba I maupun uji coba II, dampak Bahan Ajar terhadap ketuntasan belajar kognitif produk 
siswa telah melampaui angka $85 \%$. Menurut Sutirto (2013) capaian ini dapat diberi makna bahwa Bahan Ajar yang dikembangkan telah memberikan dampak terhadap ketuntasan secara klasikal. Dengan demikian dapat disimpulkan Bahan Ajar yang dikembangkan telah memenuhi kriteria keefektifan ditinjau dari hasil belajar kognitif produk. Keefektifan bahan ajar yang diperoleh dari hasil belajar kognitif produk ini juga didukung oleh data validitas dan data kepraktisan bahan ajar yang dikembangkan. Aspek validitas menunjukkan bahwa bahan ajar, termasuk dalam hal ini lembar penilaian hasil belajar produk, telah tervalidasi oleh enam validator dengan kategori valid-sangat valid. Aspek kepraktisan pada bagian keterlaksanaan RPP yang menunjukkan mudahnya bahan ajar saat diterapkan pada siswa menjadi salah satu faktor penyebab berhasilnya pembelajaran di kelas sehingga siswa dapat berhasil pada tes mereka. Aspek kepraktisan pada bagian keterbacaan Buku Siswa dan LKS juga menjadi salah satu faktor pendukung keberhasilan pembelajaran siswa, di mana dari hasil angket keterbacaan yang diberikan menunjukkan bahwa siswa memberikan penilaian yang positif terhadap Buku Siswa dan LKS yang telah mereka baca. Aspek kepraktisan pada bagian aktivitas siswa pun memberikan bukti yang linear sebagai salah satu faktor pendukung keberhasilan pembelajaran, di mana dapat dilihat bahwa hasil pengamatan aktivitas siswa menunjukkan siswa aktif selama proses pembelajaran di kelas. Keaktifan siswa selama pembelajaran ini tidak serta merta terjadi begitu saja, namun disebabkan oleh skenario yang dibuat peneliti dalam Buku Guru (RPP) sehingga dapat terwujud pembelajaran yang bersifat student center. Aspek keefektifan pada bagian respon siswa juga memberikan hasil yang linear dalam menunjukkan keefektifan bahan ajar, yaitu sebagian besar siswa memberikan respon yang positif terhadap pembelajaran yang telah mereka lakukan.

Hasil belajar kognitif proses dibedakan dalam dua dimensi, yaitu pemahaman dan kinerja. Hasil uji coba II menunjukkan 25 dari 27 siswa (93\%) tuntas. Ketuntasan siswa dalam memahami keterampilan proses sains diharapkan dapat dijadikan bekal awal bagi siswa dalam menjalani kinerja keterampilan proses sains dengan lebih baik. Dampak Bahan Ajar yang dikembangkan dilihat dari ketuntasan indikator adalah bahwa 11 dari 13 indikator $(84,62 \%)$ tuntas. Indikator yang belum tuntas adalah definisi operasional dan indikator eksperimen.

Keberhasilan siswa ini dimungkinkan juga disebabkan oleh model pembelajaran yang digunakan. Pemikiran ini didasarkan kepada pendapat Arnold et al. (2014) yang menyatakan bahwa akuisisi keterampilan inkuiri dan pembelajaran inkuiri ilmiah membantu siswa memperoleh wawasan bagaimana pengetahuan ilmiah diperoleh. Nilai-nilai dan asumsi-asumsi tersebut kemudian mampu meningkatkan pemahaman ilmiah dan kemampuan membuat keputusan (membuat simpulan).

Pemikiran sebagaimana diungkapkan di dalam paragraf di atas diperkuat oleh temuan penelitian terdahulu. Ambarsari dkk (tt) menyimpulkan bahwa inkuiri terbimbing memberikan pengaruh yang signifikan terhadap keterampilan proses sains dasar siswa. Maikristina dkk (tt) menyimpulkan bahwa model pembelajaran inkuiri terbimbing meningkatkan hasil belajar dan keterampilan proses sains yang dibelajarkan dengan menggunakan model inkuiri terbimbing memiliki ketercapaian yang lebih baik daripada model problem solving. Utami dkk (tt) menunjukkan bahwa penerapan model pembelajaran inkuiri terbimbing memberikan hasil belajar dan keterampilan proses sains lebih baik.

Kinerja proses sains siswa sangat dipengaruhi oleh Bahan Ajar yang dikembangkan baik dari komponen Buku Siswa maupun LKS. Hal ini nampak dari keberhasilannya menjalankan kinerja proses baik saat uji coba I maupun uji coba II. Hasil tes kinerja pada uji coba I menunjukkan seluruh siswa (100\%) mengalami ketuntasan belajar dengan nilai postes tertinggi 100 dan terendah 66. Hasil tes kinerja proses pada uji coba II menunjukkan bahwa 22 dari 27 siswa $(81,5 \%)$ tuntas dan lima siswa belum tuntas. Jika ketuntasan klasikal ditetapkan $85 \%$ sebagaimana disampaikan oleh Sutirto (2013), maka dapat dinyatakan secara klasikal kinerja proses siswa belum tuntas. Bagaimana dengan ketuntasan indikator? Semua indikator tes kinerja proses sains tuntas. Peneliti menilai hasil tes kinerja tidak lepas dari pengaruh tingkat pemahaman keterampilan proses sains yang dimiliki siswa. Artinya, hasil pemahaman keterampilan proses sains sejalan dan mendukung kemampuan siswa dalam kinerja keterampilan proses sains. Di samping itu, kinerja keterampilan proses sains juga menjadikan aspek psikomotorik siswa menjadi lebih aktif/lebih baik, hal ini didukung oleh pendapat/pernyataan yang disampaikan Dwijono (2013) yang menyimpulkan bahwa keterampilan proses sains yang dimiliki siswa akan mempengaruhi prestasi psikomotorik siswa.

Keberhasilan siswa ini dimungkinkan juga disebabkan oleh model pembelajaran yang digunakan. Pengalaman-pengalaman siswa dalam belajar terbimbing pada materi IPA merupakan pengalamanpengalaman yang mendorong keterampilan kinerja proses, yaitu seperti pengukuran dan lain-lain (Ausubel, 1968 di dalam Ango, 2002). Ausubel menyatakan bahwa keterampilan kinerja proses sains, seperti pengukuran dan lain-lain merupakan hal yang sangat penting untuk pengembangan pemahaman konsep sains 
dan makna penggunaan prosedur ilmiah untuk penyelesaian masalah dan aplikasi pemahaman ilmiah.

Hasil tes pemahaman dan kinerja keterampilan proses sains yang mampu meningkatkan keterampilan proses sains setelah pembelajaran juga didukung oleh hasil penelitian Purniati et al. (2009), yang menyatakan diperlukan suatu upaya untuk menciptakan proses pembelajaran yang melibatkan siswa untuk memperoleh pengetahuan. Dalam pengembangan bahan ajar fisika, model pembelajaran yang memfasilitasi siswa untuk lebih aktif diperlukan strategi belajarmengajar yang tepat. Hal yang senada disampaikan oleh Lawson et.al. dalam Iwan (2014), model inkuiri terbimbing merupakan rangkaian tahap-tahap kegiatan yang diorganisir supaya siswa menguasai kompetensikompetensi dalam pembelajaran dengan jalan berperan lebih aktif dalam proses pembelajaran. Prayogi et al, (2013) telah melakukan penelitian di mana dengan menggunakan model pembelajaran inkuiri terbimbing dapat meningkatkan keterampilan proses sains.

Keefektifan bahan ajar yang dilihat dari tes pemahaman keterampilan proses sains dan tes kinerja keterampilan proses sains dapat dikatakan mampu melatihkan keterampilan proses sains siswa. Hasil pretest keterampilan proses sains yang rendah dan hasil yang tinggi dapat dimaknai bahwa siswa pada awalnya belum mengenal keterampilan proses sains. Namun setelah mengalami pembelajaran sebanyak empat kali pertemuan dan dilakukan posttest ternyata semua indikator pemahaman dan kinerja keterampilan proses sains mengalami ketuntasan. Ketuntasan ini menjelaskan bahwa bahan ajar tersebut berhasil memudahkan guru untuk mengajar dan memudahkan siswa untuk belajar keterampilan proses sains. Data ini juga dapat dimaknai bahwa data rendah pada uji awal tidak dapat dikatakan siswa memiliki potensi akademik yang rendah, namun semata-mata mereka belum mendapatkan kesempatan untuk belajar keterampilan proses sains. Hasil belajar keterampilan proses sains ini juga mengkonfirmasi bahwa model inkuiri terbimbing dapat membelajarkan keterampilan-keterampilan inkuiri/keterampilan proses sains. Di samping hasil belajar kognitif, dengan perangkat pembelajaran menerapkan inkuiri terbimbing berhasil mewujudkan pembelajaran yang berpusat pada siswa, berbeda dengan pembelajaran berpusat pada guru yang aktivitas dominannya adalah siswa mendengarkan penjelasan guru pada saat proses belajar-mengajar dengan inkuiri terbimbing ini aktivitas siswa didominasi oleh kegiatan pengamatan dan percobaan. Hal ini juga membuat siswa senang mengikuti pembelajaran.

Penelitian terkait tentang keterampilan proses sains atau 5M yang lain pada sekolah yang sama juga menunjukkan hasil pretest yang rendah serta hasil posttest yang lebih baik/meningkat. Berdasarkan hasil pretest yang dilakukan Mahtari (2015) terhadap siswa kelas VII SMP diperoleh hasil bahwa siswa sama sekali tidak mengenal/familiar dengan keterampilan proses sains dan tidak memahami indikator-indikator keterampilan proses sains, sedangkan pada hasil posttest menunjukkan terjadi peningkatan yang signifikan bahkan mengalami ketuntasan secara klasikal. Penelitian terkait keterampilan proses sains dalam konteks yang lebih luas juga dilakukan di beberapa sekolah dasar dan menengah, baik di Surabaya oleh Iskandar (2013) maupun di luar Surabaya oleh Ummah (2015). Dari hasil telaah terhadap beberapa penelitian keterampilan proses sains pada saat pretes menunjukkan hasil yang serupa, yaitu siswa tidak mengenal keterampilan proses sains dan belum dapat mengaplikasikan indikator-indikator keterampilan proses sains pada pembelajaran IPA. Hasil-hasil posttest pun menunjukkan hal yang linear dengan hasil penelitian peneliti sekarang, yaitu terjadi peningkatan hasil belajar pada sebagian besar siswa (Iskandar, 2015; Lailiyah, 2015; dan Ummah, 2015). Hasil-hasil telaah terhadap penelitian keterampilan proses sains menunjukkan bahwa keterampilan proses sains pada sekolah yang telah menerapkan Kurikulum 2013 pun juga belum terlaksana dengan baik (Lailiyah, 2015 dan Ummah, 2015), karena sejauh ini keterampilan proses sains yang diajarkan hanya berkutat pada menganalisis dan menyimpulkan hasil percobaan/pengamatan. Data ini juga mengindikasikan bahwa guru belum siap mengajarkan Kurikulum 2013 dari aspek keterampilan proses sains secara lengkap dan menyeluruh. Bahan ajar (Silabus, RPP, Buku Guru, Buku Siswa, LKS, dan Lembar Penilaian) yang berorientasi pada $5 \mathrm{M}$ / keterampilan proses sains juga belum disiapkan dengan baik. Dari hasil kajian soalsoal Ujian Nasional (UN) pada jenjang SMP pada tiga tahun berturut-turut menunjukkan bahwa soal belum memasukkan keterampilan proses sains (Waldijah dkk, 2013). Ada kemungkinan guru tidak mengajarkan keterampilan proses sains/5M karena tidak ada tuntutan dalam UN, sehingga dampaknya guru kurang termotivasi untuk belajar dan membelajarkan keterampilan proses sains pada siswa.

Rendahnya hasil pretes keterampilan proses sains siswa yang diperoleh dalam penelitian ini serta pada beberapa penelitian sebagaimana disebutkan di atas ternyata juga serupa dengan hasil penelitian yang telah dilakukan Nur (1982), di mana dalam penelitian juga diperoleh hasil pretes keterampilan proses sains yang rendah. Hal ini dapat diartikan bahwa keterampilan proses sains siswa belum mengalami perubahan yang signifikan dari beberapa puluh tahun lalu sampai dewasa ini.

Hasil-hasil penelian terkait keterampilan proses sains di atas menunjukkan bahwa kemampuan bernalar 
siswa masih rendah. Hasil-hasil penelitian tersebut juga didukung oleh data PISA (Programme for International Student Assesment) yang menunjukkan masih rendahnya tingkat kemampuan bernalar siswa di Indonesia. Data PISA 2012 menyebutkan bahwa dari sejumlah 65 negara di dunia tercatat Indonesia berada pada peringkat ke-64 dengan skor 375 (skor tertinggi 613 dan skor terendah 368). Sejak pertama kali mengikuti tes yang dilakukan oleh OECD (Organization for Economic Co-operation) ini, yaitu pada tahun 2003, prestasi siswa Indonesian tidak pernah beranjak jauh dari posisi terbawah. Padahal di sisi lain siswa Indonesia banyak berhasil meraih kemenangan pada olimpiade sains matematika, fisika, astronomi, dan lainnya.

Hasil belajar afektif yang diamati dan dinilai meliputi afektif sikap spiritual dan afektif sikap sosial. Afektif sikap spiritual yang diamati meliputi berdoa dan mengucapkan salam. Afektif sikap sosial meliputi kerja sama, tanggung jawab, dan rasa ingin tahu. Hasil belajar afektif sikap spiritual dan afektif sikap sosial memiliki ketuntasan sebesar $100 \%$. Ketuntasan tersebut dapat terwujud dikarenakan pada saat pembelajaran indikator-indikator sikap spiritual dan sikap sosial dilatihkan. Pada saat pembelajaran guru juga mengingatkan siswa untuk disiplin, jujur, tanggung jawab, bekerja sama, mempunyai rasa ingin tahu yang tinggi, dan teliti dalam melaksanakan percobaan. Domain afektif ini digunakan oleh guru dalam pengajaran dengan menggunakan model inkuiri terbimbing. Hasil tersebut sesuai dengan pernyataan Birbeck \& Andre (2009) yang menyatakan bahwa untuk mengenali nilai atribut afektif siswa maka harus terang-terangan dikembangkan, diajarkan dan dinilai secara eksplisit, dan bukan hanya tertanam dalam tugastugas kognitif. Berdasarkan Anderson \& Krathwohl (2001), perilaku afektif berkembang ketika pengalaman belajar yang tepat disediakan bagi siswa sama halnya seperti perilaku kognitif berkembang dari pengalaman pembelajaran yang tepat. Pembelajaran menggunakan model inkuiri terbimbing dalam penelitian ini juga mendukung untuk mengajarkan sikap tersebut, sebagai contoh saat siswa mempresentasikan hasil penyelidikan di depan kelas maka mereka terlebih dahulu mengucapkan salam serta menggunakan bahasa sopan.

Hasil penilaian aspek afektif yang dimiliki siswa dapat dikatakan juga berkorelasi dengan perilaku dan kinerja siswa di kelas/laboratorium pada saat pembelajaran. Hal ini sesuai dengan penelitian Dwijono (2013) yang menyimpulkan bahwa keterampilan proses sains mempengaruhi prestasi belajar afektif.

Hasil belajar psikomotor secara keseluruhan mengalami ketuntasan yaitu dengan nilai $\mathrm{C}+\mathrm{s} / \mathrm{d} \mathrm{B}+$. Ketuntasan ini dikarenakan siswa sudah pernah diajarkan percobaan serupa pada pembelajaran sebelumnya (LKS 2), di mana selain diajarkan dan dilatih KPS siswa juga dilatih agar mandiri dalam keterampilan psikomotornya, yaitu menyiapkan alat dan bahan percobaan serta mengukur volume material. Hal ini sesuai dengan hasil penelitian Dwijono (2013), yang menyimpulkan bahwa keterampilan proses sains mempengaruhi prestasi belajar psikomotor.

\section{Temuan Penelitian}

1. Dihasilkan desain Bahan Ajar (Silabus, RPP, Buku Guru, Buku Siswa, LKS, dan LP) materi gelombang, dan bunyi yang telah memenuhi syarat validitas baik konstruk maupun validitas konten.

2. Desain Bahan Ajar telah memenuhi syarat kepraktisan ditinjau dari indikator keterbacaan oleh siswa, dukungan pelaksanaan pembelajaran, pengkondisian siswa belajar aktif, dan hambatan pembelajaran.

3. Desain Bahan Ajar telah memenuhi syarat keefektifan ditinjau dari indikator hasil belajar dan respon siswa.

\section{KESIMPULAN}

Keterampilan proses sains sangat penting dalam pembelajaran IPA karena melalui keterampilan proses sains siswa tidak hanya menerima konsep, namun siswa dilibatkan dalam membangun atau menemukan konsep. Lebih dari itu, dengan keterampilan proses sains siswa dididik untuk menjadi seorang ilmuwan. Melalui penelitian ini telah berhasil dikembangkan bahan ajar IPA SMP (materi getaran, gelombang, dan bunyi) yang dirancang untuk membelajarkan keterampilan proses sains. Bahan ajar yang dikembangkan itu telah memenuhi syarat validitas baik konstruk maupun isi, telah terbukti praktis, dan efektif. Dengan dihasilkan bahan ajar ini, kekawatiran keterampilan proses sains tidak dibelajarkan oleh guru dapat direduksi. Pada Buku Guru maupun Buku Siswa yang telah dikembangkan telah secara eksplisit mencantumkan indikator-indikator keterampilan proses sains secara lengkap. Di samping memuat indikator-indikator keterampilan proses sains, bahan ajar yang dikembangkan feasible untuk mendukung pembelajaran yang direkomendasikan untuk pembelajaran IPA di SMP, yaitu model pembelajaran inkuiri terbimbing. Menggunakan bahan ajar yang telah dikembangkan, pembelajaran keterampilan proses sains seperti: merumuskan hipotesis, mengidentifikasi variabel, merumuskan definisi operasional variabel, mencatat dan menyajikan data dalam bentuk tabel, menganalisis data, dan merumuskan simpulan dapat dengan mudah direalisasikan. Pembelajaran dengan inkuiri efektif dalam membantu siswa memahami konsep dan penggunaan keterampilan proses sains. 


\section{REFERENSI}

Ambarsari, W. Santosa, S. Marldi. (tt). Penerapan Pembelajaran Inkuiri Terbimbing terhadap Keterampilan Proses Sains Dasar pada Pelajaran Biologi Siswa Kelas VIII SMP Negeri 7 Surakarta. Jurnal Pendidikan.

Anderson, W. and Krathwol, D. R. (2001). A Taxonomy for Learning Teaching and Assessing, a revision of Blooms Taxonomy of Educational Objectives. New York: Longman.

Ango, Mary L. (2002). Mastery of Science Skills and Their Effectiv Use in The Teaching of Science: An Educology of Science Education in the Nigerian Context. International Journal of Educology. 16 (1).

Arnold, J C, Kremer, Kerstin, and Mayer, J. (2014). Understanding Students' Experiments - What kind of support do they need in inquiry tasks. International Journal of Sciece Education. 36 (16), $2719-2749$.

Birbeck, D. and Andre, K. (2009). The Affective Domain: Beyond Simply Knowing. ATN Assesment Conference 2009, RMIT University.

Borich, G. D. (1994). Observation Skills for Effective Teaching. 2nd Ed. New York: Macmillan Publishing Company.

Dwijono., Sunarno, W., dan Sugiyanto. (2013). Pembelajaran Biologi dengan Pendekatan Starter Eksperimen (PSE) Melalui Inkuiri terbimbing dan Inkuiri Bebas Termodifikasi Ditinjau dari Keterampilan Proses Sains dan kreativitas Siswa. Jurnal Inkuiri. 2 (2), 124 - 133.

Iskandar, J. (2015). Pengembangan Prototipe Buku Guru dan Buku Siswa Kurikulum 2013 pada Materi Suhu dan Pemuaian untuk Melatihkan Berpikir Kreatif. (Tesis tidak dipublikasikan), Universitas Negeri Surabaya, Surabaya.

Jannah, L. dan Nur, M. (2015). Reviu Kelayakan Buku Ajar IPA SMP Kurikulum 2013 Ditinjau dari AAAS." Jurnal Seminar Nasional Unesa. 1383 1392.

Kemendikbud. (2014). Materi Pelatihan Guru Implementasi Kurikulum 2013 Mata Pelajaran IPA SMP/MTs. Jakarta: Kemendikbud.

Kemendikbud. (2014). Permendikbud Nomor 71 Tahun 2013 Tentang Buku Teks Pelajaran.

Kemendikbud. (2014). Permendikbud Nomor 81 A
Tahun 2013 Tentang Standar Proses.

Kuhlthau, C., Maniotes, Leslie. K., Caspari, and Ann. K. (2007). Guided Inquiry (Learning in the 21 $1^{\text {st }}$ Century). Washington DC: National Academy Press.

Maikristina, N., Dasna, I. W., dan Sulistina, O. (tt) "Pengaruh Penggunaan Model Pembelajaran lnkuiri terhadap Hasil Belajar dan Keterampilan Proses Sains Siswa Kelas XI IPA SMAN 3 Malang pada Materi Hidrolisis Garam. Jurnal Pendidikan.

Nieveen, N. and Plomp, T. (2007). An Introduction to Educational Design Research. Netherland: Netherlands institute for curriculum development.

Nur, M. (1982). Kompetensi Akademik Mahasiswa FKIE IKIP Jurusan Biologi, Fisika dan Kimia Dintinjau dari Peranannya dalam Mengelola Kegiatan Inkuiri sebagai Dasar Pengembangan Pembelajaran Sains di Sekolah Menengah Atas. (Disertasi Pascasarjana tidak dipublikasikan), IKIP Bandung.

Prastowo, A. (2013). Panduan Kreatif Membuat Bohan Ajar lnovatif. Jogjakarta: DIVA Press.

PISA. (2012). Result and Focus. Snapshot of Performance in Mathematics, Reading, and Science.

http://www.oecd.org/pisa/keyfindings/PISA2012-results-snapshot-Volume-I-ENG-pdf.

Diakses 8 januari 2016.

Ratumanan, G.T, Laurens (2006). Evaluasi Hasil Belajar Pada Tingkat Satuan Pendidikan. Surabaya: Unesa Press.

Sanjaya, W. (2009). Perencanaan dan Desain Sistem Pembelajaran. Jakarta: Kencana.

Sugiyono. (2014). Metode Penelitian Kombinasi (Mixed Methods). Bandung: ALFABETA..

Sutirto, M. dan Yulian. (2013). Pengembangan Perangkat Pembelajaran Fisika SMK Berorientasi Inkuiri Dengan Laboratorium Virtual untuk Melatihkan Keterampilan Proses Sains. (Tesis yang tidak dipublikasikan), Pascasarjana Universitas Negeri Surabaya.

Thiagarajan, S. Sempmel, D.S. and Sammel, M.I. (1974). Instruction Development for Training Teachers of Exeptionaf Children. Indiana: Indiana University Bloominton. 